\title{
Electronic Information Board Based on AVR Atmega128 for TEWS in Cilacap
}

\author{
Galih Mustiko Aji ${ }^{1}$, Artdhita Fajar Pratiwi ${ }^{2}$, Purwiyanto $^{3}$, Chairunnisa ${ }^{4}$, Achmad Munir ${ }^{5}$ \\ ${ }_{1,2,3}$ Department of Electronics Engineering, State Polytechnic of Cilacap, Indonesia \\ ${ }^{4,5}$ Radio Telecommunication and Microwave Laboratory, School of Electrical Engineering and Informatics, Institut \\ Teknologi Bandung, Indonesia
}

\begin{abstract}
Article Info
Article history:

Received Sep 09, 2017

Revised Apr 27, 2018

Accepted May 11, 2018

\section{Keywords:}

Dot matrix

Tsunami Early Warning System (TEWS)

Wireless

ABSTRACT

Dissemination methods of tsunami Information in Cilacap uses voice and siren. There are some constraints on the methods, especially in social aspects for particular society. Utilization of electronic information board is one of alternative solutions that can be offered to the society in responding tsunami information or warning. In this paper, a wireless electronic information board is designed to display the tsunami disaster warning visually. In normal condition or when there is no disaster, the information board can be utilized to display the information about evacuation procedure. The proposed electronic information board is implemented in multicolor using three sets of LED dot matrix panel P10 which have $32 \times 16$ pixels resolution and is controlled using microcontroller. The result showed that this device was capable to show the tsunami information such as "Status Awas", "Status Siaga", "Status Waspada", and "Evacuation Route".
\end{abstract}

Copyright $\odot 2018$ Institute of Advanced Engineering and Science. All rights reserved.

\section{Corresponding Author:}

Artdhita Fajar Pratiwi,

Department of Electronics Engineering, State Polytechnic of Cilacap, Indonesia.

Email: artdhita.pratiwi@gmail.com

\section{INTRODUCTION}

Cilacap is one of districts in Central Java Province which is located on the confluence of two major plates, which are Indo-Australian plate and Asia plate [1]. Cilacap district has the biggest coastal area in Central Java which spread out along 70,709 km. Based on Indonesia Disaster Index 2011, Cilacap is one of the top 3 districts with the highest disaster threat of tsunami [2]. As the prone area to tsunami disaster, local goverment of Cilacap must implement an early warning system to anticipate the worse risk of tsunami disaster. Having a Tsunami Early Warning System (TEWS) during the tsunami disaster is important because it can decrease the damage and victims of tsunami. The early warning is not only about giving accurate warning information, but also building a good risk of understanding about the warning and increasing the society's ability to react correctly in responding the early warning. To be effective and complete, an early warning system needs to comprise four interacting elements, i.e (i) risk knowledge, (ii) monitoring and warning service, (iii) dissemination and communication, and (iv) response capability [3]. Each element interacts each other. Knowledge of the relevant hazards has direct linkage with reponse capability for timely and appropriate action. Moreover, a technical capacity to monitor hazard precursors or to forecast the hazard evolution is useless without understandable dissemination and communication methods as prior preparedness information.

In Cilacap district, which has disaster threat of tsunami, the dissemination method of tsunami information is becoming important due to this information is going to be spreaded out to the society. Currently, dissemination methods of tsunami information in Cilacap has been deployed through straightforward approach using voice and siren [4]. Unfortunately, those methods have some constraints especially in social aspects for particular society. Sometimes, the society could not distinguish between the 
simulation and the real tsunami warning. Furthermore, inaccurate information due to some noises from the device affects anxiety in society. The voices from speaker or sound truck should be flawless since any mistakes are going to initiate a serious problem in society (misunderstanding) [5], [6]. Regarding to those issues, utilization of electronic information board is one of alternative solutions that can be offered to the society in responding tsunami information or warning. The design and implementation of wireless electronic information board for tsunami early warning system are discussed in this paper. The system is expected to be implemented in some points along Cilacap coastal. Wireless network approach has been choosen due to its unrestricted potential for numerous applications including environmental, crisis management during the disaster, medical, defense, etc [7]. There are some different kinds of wireless network based upon the specific characteristics [8]. By considering the lack of information, the wireless network, such as Never Die Network and Cognitive Wireless Network, can be possible for disseminating the disaster information [9], [10]. Eventhough the cables are broken and blackout, a wireless network system is able to reactivate quickly. An electronic information board is designed to display the tsunami warning information or evacuation procedure. The implementation of the system is expected to provide information visually to the public about the risks and the actions to be taken during tsunami disaster.

\section{DESIGN OF ELECTRONIC INFORMATION BOARD}

The proposed electronic information board is utilized to display the tsunami warning and suggestion visually. All the warning information which displays on the information board should follow the manual book of Indonesia Tsunami Early Warning System [11]. In Indonesia, an early warning system is started from National Meteorology, Climatology, and Geophysics Department (Badan Meteologi, Klimatologi, dan Geofisika, BMKG). BMKG provides an earthquake information or tsunami early warning information, and sends it to related institution, such as National Disaster Relief Department (Badan Nasional Penanggulangan Bencana, BNPB), Local Government, media, etc. The tsunami warning is sent through some communication networks, such as VSAT, GSM, internet, telephone, fax, Digital Video Broadcasting (DVB), and radio communication. Then, the information is delivered and followed up by the society. The local government is expected to make an evacuation decision if it is required. Then, BMKG publishes earthquake information or tsunami early warning information in five minutes after earthquake happens, followed by some updated information and it is ended by information that the tsunami threat has over.

Local government which receives the news from BMKG has to give an instruction for evacuation to the society in the disaster area. The earthquake Information or tsunami early warning information and suggestion form BMKG should be received accurately all day through any communication devices. Local government is expected to make a decision for further action which is needed for their location correctly whether evacuation is necessary or not. In InaTEWS manual book, there are three standards of tsunami threat level:

- $\quad$ Tsunami level $>3$ meters, the threat level status is huge tsunami.

- Tsunami level 0.5-3 meters, the threat level status is tsunami.

- Tsunami level $<0.5$ meter, the threat level status is tsunami notice.

Based on the standard, the proposed electronic information board is designed to display the tsunami warning, "Status Awas" for tsunami level $>3$ meters, "Status Siaga" for tsunami level $0.5-3$ meters, and "Status Waspada" for tsunami level $<0.5$ meter. The information board can also display the earthquake or tsunami information, such as evacuation route, assembly point or evacuation procedure. Block diagram of the proposed system shown in Figure 1 is featured with LED dot matrix panel which is driven by microcontroller ATMega128. The received signal from Local Disaster Relief Department (Badan Penanggulangan Bencana Daerah, BPBD) is converted into digital signal through FSK demodulator to be passed through for LED dot matrix panel [12]. The transmission data has BER value of $0.2 \%$, means there are 49 characters transmissible continously without any error.

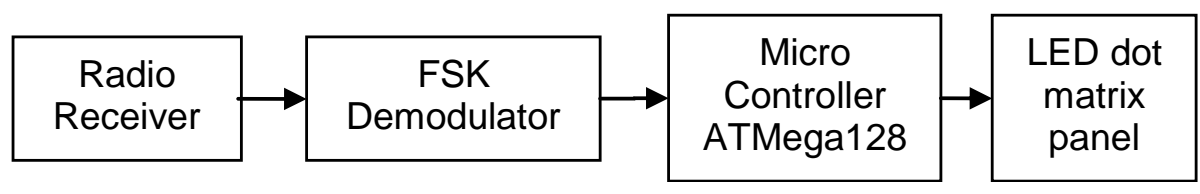

Figure 1. Block diagram of the proposed electrrical information board

The display panel consists of three colors dot matrix panel as shown in Figure 2. It is necessary to distinguish the tsunami level, red for "status Awas" or "status Siaga", yellow for "status Waspada", and 
green for Earthquake or tsunami info, as presented in Table 1. The proposed display board uses three sets of LED dot matix panel P10 which have 32 x 16 pixels resolution. For minimum specification, it requires $96 \times$ 48 pixels minimum to display the information clearly.

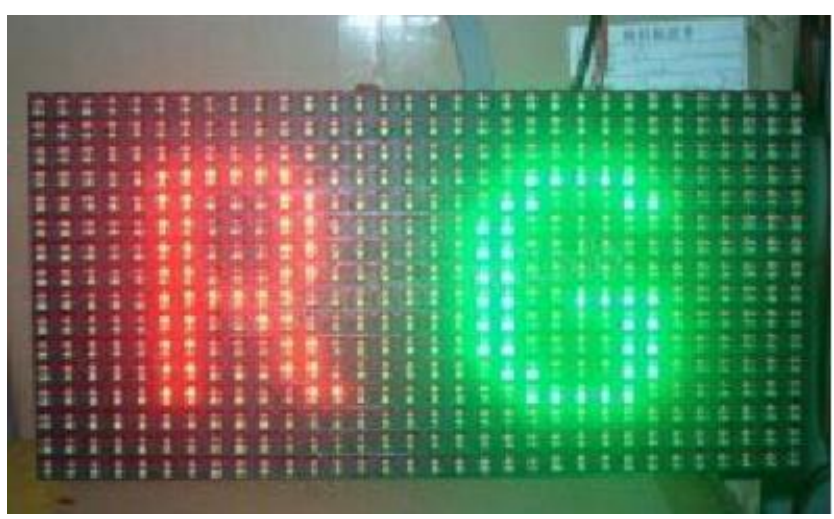

Table 1. Tsunami Early Warning Levels and

\begin{tabular}{ccc}
\multicolumn{3}{c}{ Instructions to Society } \\
\hline Status & Instruction & Color \\
\hline AWAS \& SIAGA & Evacuation & RED \\
WASPADA & $\begin{array}{c}\text { Keep Away from } \\
\text { Coast and River } \\
\text { Tsunami } \\
\text { Earthquake/Tsunami } \\
\text { Info }\end{array}$ & $\begin{array}{c}\text { Evacuation is } \\
\text { Unnecessary }\end{array}$ \\
\hline
\end{tabular}

Figure 2. Three colors LED dot matrix panel

\section{INTERFACING OF LED DOT MATRIX PANEL}

The proposed electronic information board is implemented using LED dot matrix panel P10 RG with HUB-75 connector model. The panel is connected to microcontroller ATMega128 with the configuration as shown in Figure 3. The configuration of HUB-75 connector model in LED dot matrix panel is illustrated in Figure 4 with the description tabulated in Table 2.

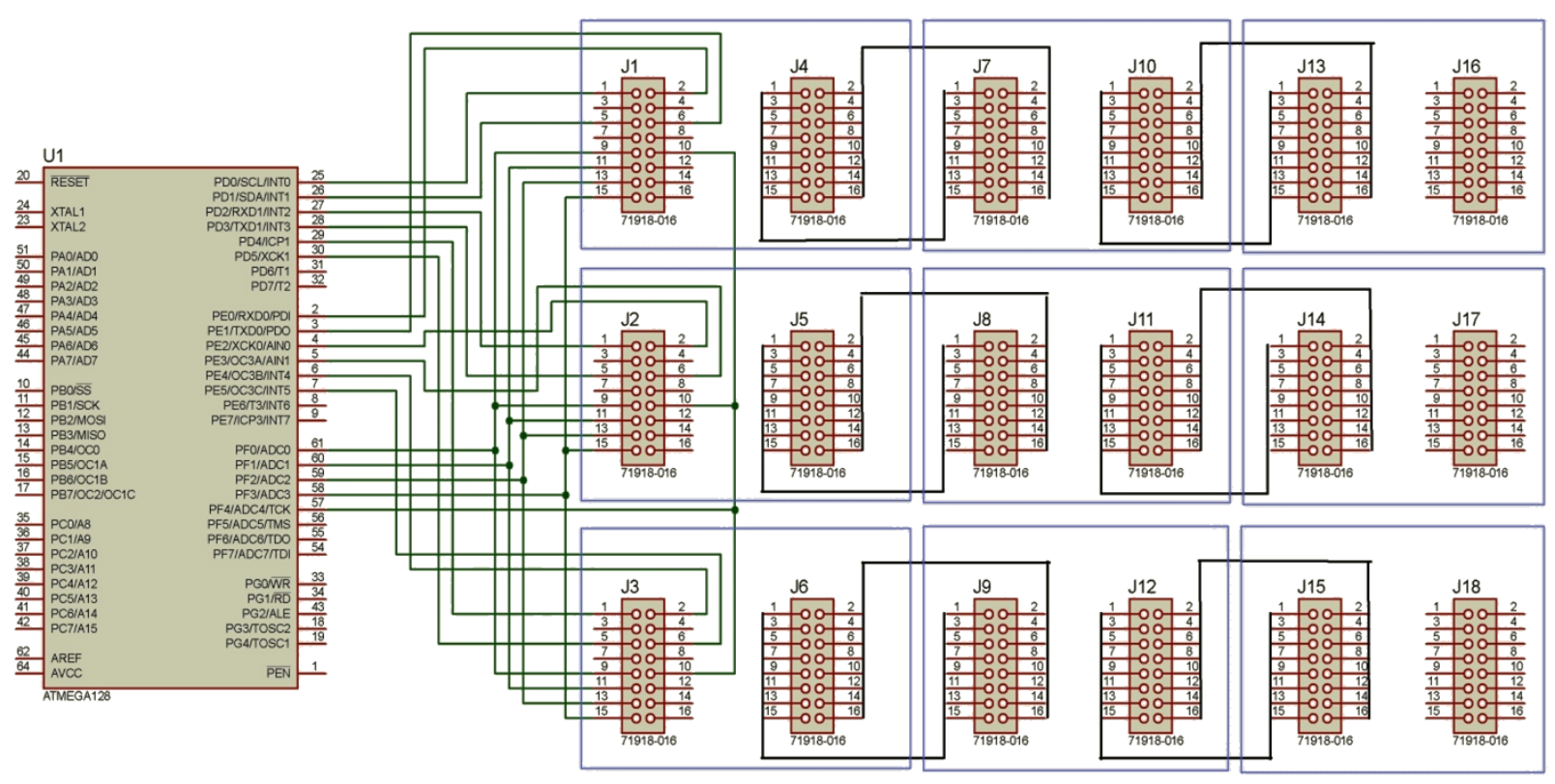

Figure 3. Interface schematic configuration of microcontroller and LED dot matrix panel 


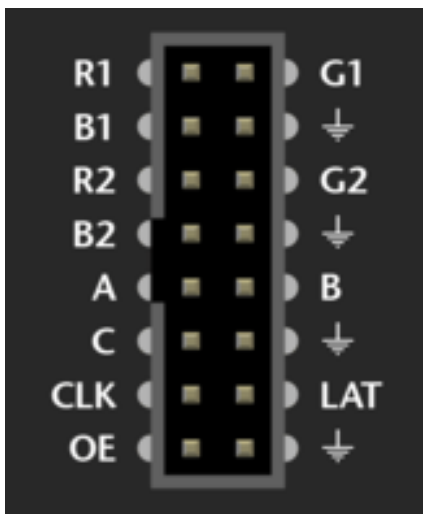

Table 2. Description of HUB-75 Connector Model

\begin{tabular}{cl}
\hline Port & \multicolumn{1}{c}{ Description } \\
\hline R1, R2 & Red data serial \\
G1, G2 & Green data serial \\
B1, B2 & Blue data serial \\
A, B, C & Address line \\
CLK & Clock \\
OE & Enabled \\
LAT & Latch \\
Gnd & Ground \\
\hline
\end{tabular}

Figure 4. Configuration of HUB-75 connector model

To activate one frame of LED dot matriks panel $32 \times 32$ pixels, the data should be sent in serial per 1 byte at register as depicted in Figure 5. Each frame of LED dot matrix panel requires 64 bytes of memories. For the minimum specification of 96 x 48 pixels, the display board involves nine sets of LED dot matrix panel. It means the proposed electronic information board needs 576 bytes of memories for each frame.

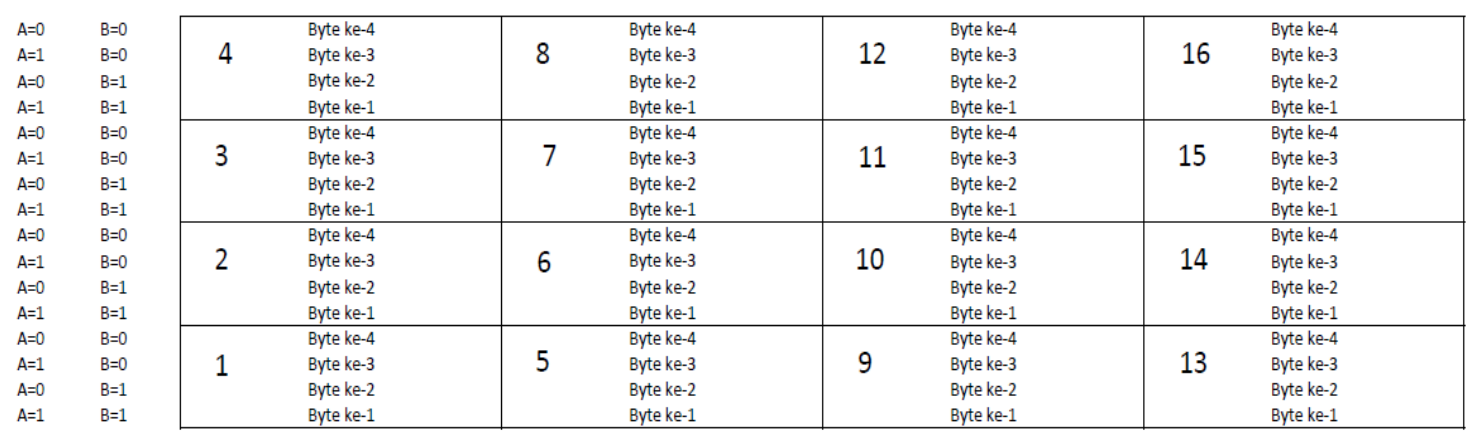

Figure 5. Register address of LED dot matriks panel

\section{RESULTS AND DISCUSSIONS}

There are 8 frames of the information which can be displayed on the electronic information board as summarized in Table 3.

Table 3. Information of Each Frame

\begin{tabular}{ccc}
\hline Status & Frame & Information \\
\hline Aman & 1 & "Arah Evakuasi" \\
& 2 & "Titik Kumpul" \\
& 3 & "Titik Berpotensi \\
Tsunami" \\
Siaga & 4 & "Status Siaga" \\
& 5 & "Jauhi Pantai dan \\
Waspada & 6 & Sungai" \\
& 7 & "Status Waspada" \\
Awas & 8 & "Status Awas" \\
& 7 & "Segera Mengungsi" \\
\hline
\end{tabular}

Based on the memory consumption, since 1 frame requires 576 bytes of memory, it means all the information which are going to be displayed need 576 bytes $\times 8$ frames $=4.608$ bytes of memories. Unfortunately, microcontroller ATmega128 has only 4 Kbytes internal EEPROM which means that the memory of microcontroller is not sufficient. So, this system needs additional EEPROM AT24C512 to 
support the memory. Figure 6, Figure 7, dan Figure 8 show the tsunami warning and the instruction that should be followed. Figure 9 shows other tsunami information if there is a small earthquake. This electronic information board shows the tsunami warning and instruction one after the other ones in couple seconds and are repeated until the threat is over.
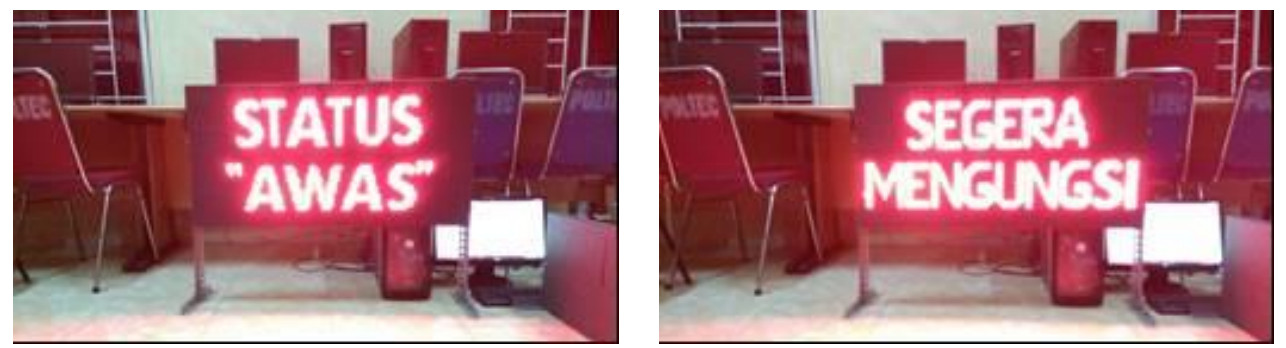

Figure 6. Tsunami warning "status awas
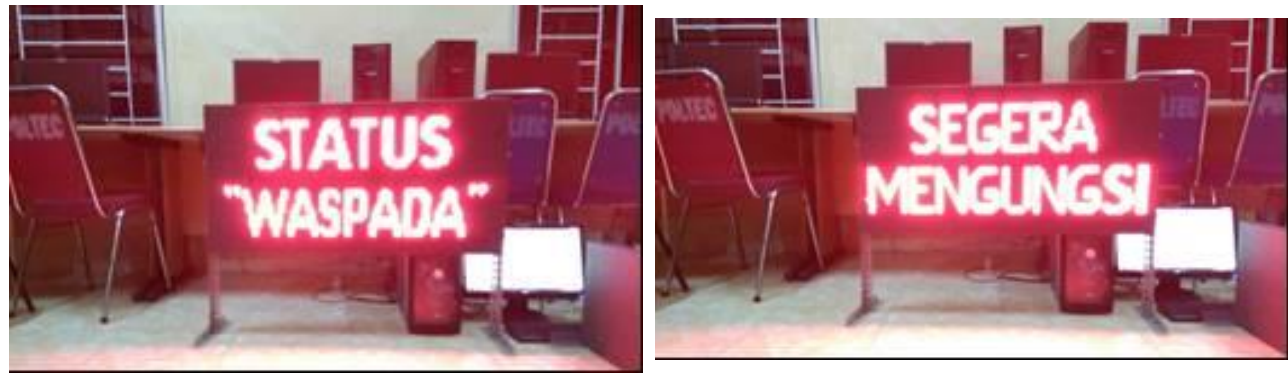

Figure 7. Tsunami warning "status siaga"
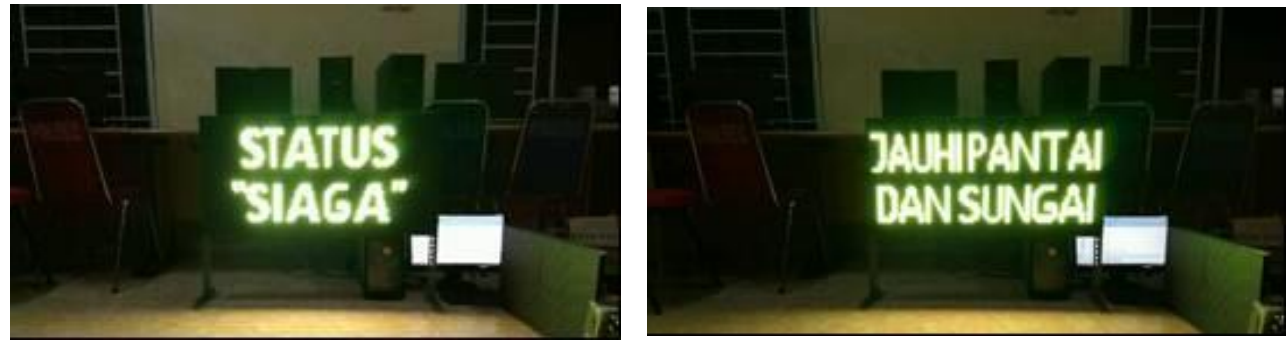

Figure 8. Tsunami warning "status waspada"

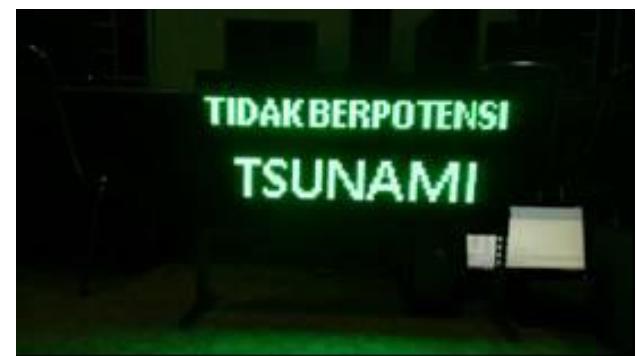

Figure 9. Tsunami information 
In normal condition or when there is no disaster, the proposed electronic information board is usable to spread out the information about the evacuation route and assembly point as shown in Figure 10 and Figure 11.

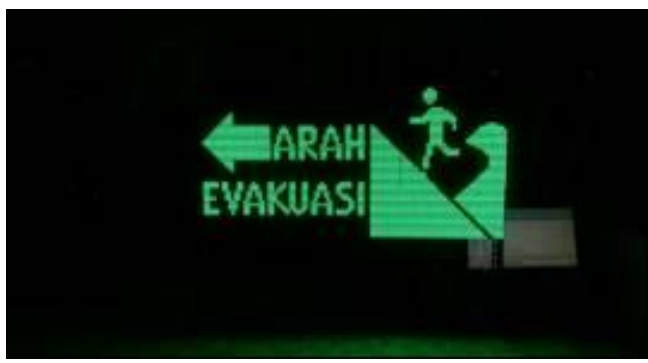

Figure 10. Evacuation route

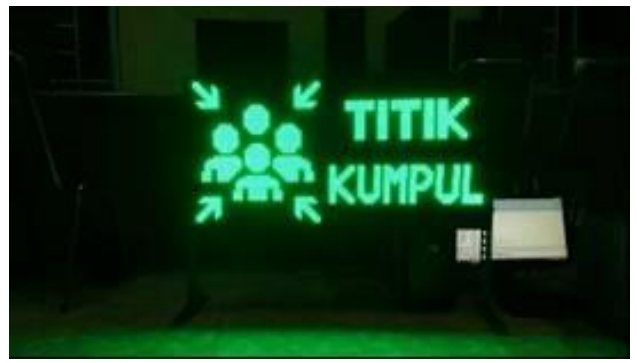

Figure 11. Assembly point

This system is going to be implemented using radio frequency (RF) transmission which has BER value of $0,2 \%$ [12]. That means there are 11 bytes of error to display one frame of information which is used 576 bytes. It is not possible to transmit one frame of information from main control to the electronic information board without any information error. To minimize the error, the information to be displayed has to be stored in the electronic display board. So, the main control only needs to send any particular code to display the information in electronic display board.

\section{CONCLUSION}

The design and implementation of electronic information board for tsunami early warning system has been presented. Three sets of LED dot matrix panel P10 with $32 \times 16$ pixels resolution has been used for the implementation controlled using microcontroller ATmega128. To display the information clearly, the information board requires minimum specification of $96 \times 48$ pixels resolution. As the results, this device was success to show the tsunami information such as "Status Awas", "Status Siaga", "Status Waspada", "Evacuation Route" and other tsunami information.

\section{REFERENCES}

[1] Mahendra WA, Armono HD, Sambodho K. Studi Analisis Ketahanan Masyarakat Pesisir Cilacap Terhadap Bencana Tsunami. Jurnal Teknik Pomits. 2013; 2(1): 1-12.

[2] Badan Nasional Penanggulangan Bencana. Indeks Rawan Bencana Indonesia. Jakarta: BNPB. 2011.

[3] Basher R. Global Early Warning Systemms for Natural Hazards: Systematic and People-Centred. Philosophical Transactions of The Royal A Society. 2006; 364: 2167-2182.

[4] Badan Meterologi Klimatologi dan Geofisika. Pedoman Pelayanan Peringatan Dini Tsunami. Jakarta: BMKG. 2012

[5] Schnitzler J, Benzler J, Altmann D, Mücke I, Krause G. Survey on The Polipations Needs and The Public Health Response during Floods in Germany 2002. Journal Public Health Management Practice. 2007; 13(5): 461-464.

[6] Zhang N, Huang H, Su B, Zhang H. Population Evacuation Analysis: Considering Dynamic Population vulnerability Distribution and Disaster Information Dissemination. National Hazard. 2013; 69(3): 1629-1646.

[7] Tarun D, Sahu OP. Survey on Wireless Sensor Networks for Reliable Life Services and Other Advanced Applications. Indonesian Journal of Electrical Engineering and Informatics (IJEEI). 2013; 1(4): 133-139.

[8] Toor AS, Jain AK. A Survey on Wireless Network Simulators. Bulletin of Electrical Engineering and Informatics (BEEI). 2017; 6(1): 62-69.

[9] Uchida N, Takahata K, Shibata Y, Shirotori N. Never Die Network Extended with Cognitive Wireless Network For Disaster Information System. Journal of Wireless Mobile Networks, Ubiquitous Computing, and Dependable Applications. 2012; 3(3): 74-93.

[10] Sato G, Uchida N, Asahizawa D, Shibata T. Power Saving Radio LANS for Disaster Information System. Proceedings of IEEE 12th International Conference on Network-Based Information Systems (NBiS). Indianapolis. 2009: 592-596.

[11] Badan Meterologi Klimatologi dan Geofisika. InaTEWS Indonesia Tsunami Early Warning System, Konsep dan Implementasi. Jakarta: BMKG. 2010.

[12] Pratiwi AF, Aji MA, Purwiyanto, Chairunnisa, Munir A. Wireless Electronic Information Board for Tsynami Early Warning System Based on FM Radio. Proceedings of 7th International Annual Engineering Seminar. Yogyakarta. 2017: 139-142. 